\title{
Zooplankton functional complementarity between temporary and permanent environments
}

\author{
Complementariedade funcional zooplanctônica entre ambientes aquáticos temporários e \\ permanentes
}

\section{Rayanne Barros Setubal ${ }^{1 *}$ (D) and Reinaldo Luiz Bozelli ${ }^{1}$}

${ }^{1}$ Laboratório de Limnologia, Departamento de Ecologia, Instituto de Biologia, Universidade Federal do Rio de Janeiro - UFRJ, Av. Carlos Chagas Filho, 373, CP 68020, CEP 21941-590, Rio de Janeiro, RJ, Brasil

*e-mail: setubal.rb@gmail.com

Cite as: Setubal, R.B. and Bozelli, R.L. Zooplankton functional complementarity between temporary and permanent environments. Acta Limnologica Brasiliensia, 2021, vol. 33, e3.

Abstract: Aims: This study aims to evaluate the functional complementarity of the zooplankton community between temporary ponds and permanent lagoons. We hypothesize that temporary environments will be functionally more diverse than permanent environments and will have different functional composition. Methods: Five temporary ponds and five permanent lagoons were compared regarding their limnological characteristics, species richness, functional diversity indices and functional trait composition. Results: No differences between ponds and lagoons were found regarding mean species richness and functional diversity. However, a larger number of species was found in the set of temporary environments i.e., although the mean richness was the same, the species' identity varied from one pond to another. Ponds showed greater variability in functional trait composition, resulting in significant differences in zooplankton functional dispersion. Ponds also presented a greater range of limnological characteristics. Conclusions: Temporary and permanent environments present high limnological and functional complementarity, which make them important for maintaining biodiversity on a regional scale. Temporary environments seem to be refugees for species that do not settle in more stable environments because these species are more likely to colonize environments that periodically restart their successional trajectory. Therefore, actions that seek to preserve complementary environments are essential and urgent, especially those related to small and temporary environments.

Keywords: functional dispersion; ponds; lagoons; functional diversity; species richness.

Resumo: Objetivo: Este estudo tem como objetivo avaliar a complementaridade funcional da comunidade zooplanctônica entre poças temporárias e lagoas permanentes. Nossa hipótese é de que ambientes temporários serão funcionalmente mais diversificados que ambientes permanentes e terão composição funcional diferente, sendo complementares entre si. Métodos: Cinco lagoas e cinco poças foram comparadas quanto às características limnológicas, riqueza de espécies, índices de diversidade funcional e composição de características funcionais. Resultados: Não foram encontradas diferenças significativas entre lagoas e poças em relação à riqueza e diversidade funcional. Todavia, uma maior variabilidade de espécies foi encontrada no conjunto de ambientes temporários, ou seja, embora a riqueza média tenha sido a mesma, a identidade das espécies variou de uma poça para outra. Poças apresentaram maior variabilidade na composição de traços funcionais, resultando em diferenças significativas nos valores de dispersão funcional. Poças apresentaram também uma maior amplitude de variação das características limnológicas. Conclusôes: Ambientes temporários e permanentes apresentam alta complementaridade limnológica e funcional, o que os torna importantes para a 
manutenção da biodiversidade em escala regional. Ambientes temporários parecem ser refúgios de espécies que não se estabelecem em ambientes mais estáveis, porque essas espécies têm maior probabilidade de colonizar ambientes que reiniciam periodicamente sua trajetória sucessional. Açóes que buscam preservar ambientes complementares são essenciais e urgentes, principalmente aquelas direcionadas a ambientes pequenos e temporários.

Palavras-chave: dispersão funcional; poças; lagoas; diversidade funcional; riqueza de espécies.

\section{Introduction}

Continental aquatic environments occupy about $6.5 \%$ of the Earth surface, however their importance in economic and social terms transcend their geographical boundaries (Russi et al., 2013). Continental aquatic environments are responsible for providing a variety of ecosystem services essential to mankind such as water supply, fishery products, areas for cultural and leisure activities, climate control, flood control, among others (Junk et al., 2013; Bozelli et al., 2018). Understanding the functioning of these environments is essential for the maintenance of the well-being of human societies and to support life on general (Humbert \& Dorigo, 2005; Gessner et al., 2004; Esteves et al., 2008). However, despite their recognized importance, continental aquatic environments are among the most threatened ecosystems worldwide. Climate change, pollution and dumping of domestic and industrial waste, pesticide contamination, biological invasions, silting and destruction of habitats are the main threats to continental aquatic environments (Calhoun et al., 2017; Hunter Junior et al., 2017; Junk et al., 2013; Esteves et al., 2008). In the next decades a large part of aquatic environments will be drastically modified by anthropic activities in many countries around the world (Scarano, 2019; Day \& Rybczyk, 2019; Gozlan et al., 2019) and the impacts generated by emerging pollutants that are still poorly studied, such as microplastics, artificial hormones and organic nanoparticles comprise a new challenge for the conservation of continental aquatic environments (Oskarsson \& Wright, 2019; Al-Thawadi, 2020).

Among continental aquatic environments, small wetlands such as temporary ponds are the most commonly neglected water body (Hunter Junior et al., 2017; Bozelli et al., 2018; Calhoun et al., 2017). This type of water body is characterized by a dry phase occurrence as a consequence of hydroregime variability (frequency of desiccation and inter or intra-seasonal flood variation rate) and by the high temporal species turnover (Meester et al., 2005; Seminara et al., 2008; Brendonck et al., 2017). Studies have shown that temporary ponds contain a wide range of unique species adapted to the specific conditions of these environments (Fonseca et al., 2018; Meester et al., 2005; Calhoun et al., 2017) and contribute to the maintenance and conservation of biodiversity (Bozelli et al., 2018; Hunter Junior et al., 2017). Furthermore, despite their small size, these environments present a disproportionate contribution to ecosystem processes compared to larger and more stable environments such as lakes (Biggs et al., 2017; Calhoun et al., 2017). For example, studies evaluating decomposition of allochthonous material and productivity in these environments have found high rates when compared to other aquatic environments or the surrounding terrestrial landscape (Rubbo et al., 2006; Hunter Junior et al., 2017). Therefore, such small wetlands can be essential for the maintenance of ecosystem services mediated by biodiversity on a local and regional scale.

Given the threats imposed to aquatic environments, especially temporary ponds, the complementarity between different environments is an important feature for biodiversity maintenance (Vane-Wright et al., 1991; Pressey et al., 1993; Margules \& Pressey, 2000). In conservation terms, complementarity can be defined as a measure of a certain area extension or set of areas that contribute to features not contemplated in previously established areas (Margules \& Pressey, 2000). In this sense, complementarity is often based on the choice of locations that include a greater diversity of ecosystem types (e.g. vegetation types) and/or species (e.g. fish, butterflies, birds, etc.) (Vane-Wright et al., 1991). However, the term has been used at different levels of organization and for various purposes, such as studies on niche complementarity (Kahmen et al., 2006), complementarity of functional traits (Loreau et al., 2001), complementarity of prey-use (Norberg, 2000), among others. Therefore, objectively, complementarity can be understood as the property of sets of objects that exists when at least some of the objects in one set differ from the objects in another set (Williams, 2011).

Recently, the term complementarity has taken a prominent role in studies of functional diversity as a way to quantify the extent of 
differences in the functional traits of a group of species (Petchey, 2003; Petchey \& Gaston, 2002; Burkepile \& Hay, 2011; Tilman et al., 1997). Thus, functional diversity is expected to increase as the magnitude of differences between the functional traits of species increases (Tilman et al., 1997). Similarly, two environments can be considered functionally complementary depending on the differences among the functional properties of their communities. Thus, the use of functional diversity indexes together with the evaluation of the functional trait composition can be an interesting tool to understand complementarity relations of different environments, especially in face of environmental changes. For example, Setubal et al. (2020) illustrated, through functional diversity measures, the role of community complementarity in maintaining the ecosystem processes under environmental changes promoted by hydrological variations. Therefore, an analysis of the community functional complementarity in light of their potential different responses to environmental variability allows a better understanding of ecosystem dynamics (Walker et al., 1999; Elmqvist et al., 2003; Mori et al., 2013).

Within this context, the objective of this study is to evaluate the functional complementarity of the zooplankton community between temporary and permanent environments. Zooplankton community is important for several ecosystem processes related to material flow, nutrient cycling and ecosystem functioning (Barnett \& Beisner, 2007). Then, efforts to understand how these environments complement each other in order to maintain functional diversity on a regional scale are urgent to support conservation strategies. We hypothesize that the temporary ponds, as they present greater short-term variability, will be more diverse and will present a different taxonomic and functional composition of the zooplankton community than that found in permanent lagoons.

\section{Methods}

\subsection{Study area}

This study was performed in five permanent coastal lagoons (Bezerra, Jurubatiba, Carapebus, Comprida and Paulista) and five temporary ponds (Ponds 1, 2, 3, 4 and 5) located within the Restinga de Jurubatiba National Park, in the northern region of the state of Rio de Janeiro, Brazil $\left(22^{\circ}\right.$ to $22^{\circ} 30^{\prime} \mathrm{S}$ and $41^{\circ} 15^{\prime}$ to $42^{\circ} \mathrm{W}$ - Figure 1$)$. Restinga consists of a coastal Holocenic sandy plain with lagoons and temporary ponds transitioning to sand dunes and a

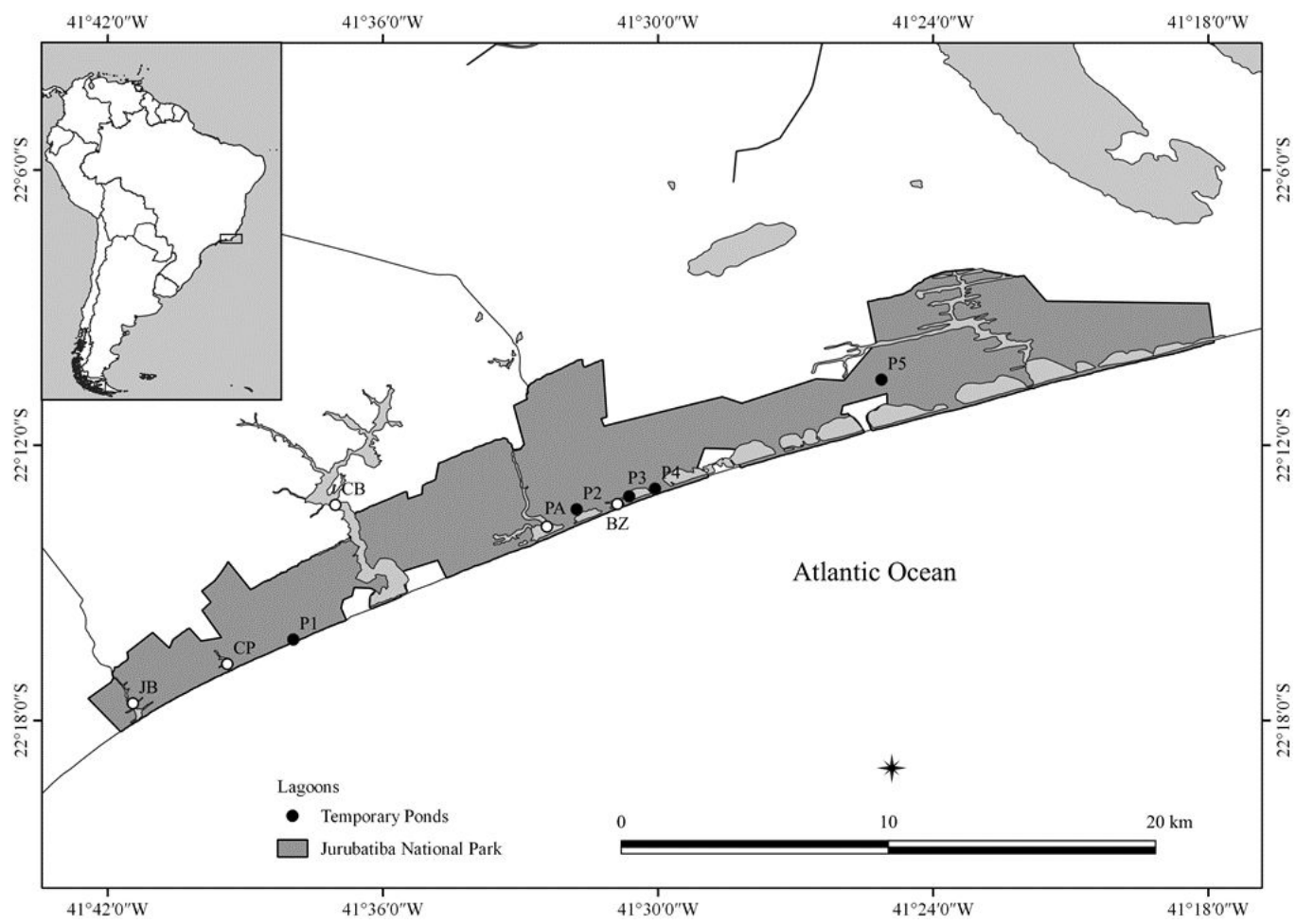

Figure 1. Geographical location of permanent lagoons and temporary ponds located in Jurubatiba National Park, Rio de Janeiro, Brazil. JB = Jurubatiba lagoon; $\mathrm{CP}=$ Comprida lagoon; $\mathrm{CB}=$ Carapebus lagoon; $\mathrm{PA}=$ Paulista lagoon; $\mathrm{BZ}=$ Bezerra lagoon; $\mathrm{P} 1=$ Pond $1 ; \mathrm{P} 2=$ Pond $2 ; \mathrm{P} 3=$ Pond $3 ; \mathrm{P} 4=$ Pond $4 ; \mathrm{P} 5=$ Pond 5. 
mosaic of shrub-dominated plant communities. The climate alternates between a wet season (October to April) and a dry season (May to September), with a mean summer temperature of $25^{\circ} \mathrm{C}$ and an average winter temperature of approximately $19^{\circ} \mathrm{C}$. The annual precipitation is $1,165 \mathrm{~mm}$, and there is a pronounced seasonal distribution, with monthly minimum precipitation occurring from May to September $(40 \mathrm{~mm})$ and maximum precipitation occurring from October to April $(190 \mathrm{~mm})$ (Caliman et al., 2010).

The permanent lagoons chosen for this study are coastal, shallow and primarily supplied with freshwater from rivers which makes their hydroperiod longer than 10 years. All of the lagoons are oriented perpendicular to the sea with the exception of Bezerra lagoon, which is parallel to it. Because of their position near the shoreline, saltwater intrusion may occur, increasing lagoon's salinity. Variations in limnological features, particularly in the concentrations of salt, nutrients and chlorophyll- $a$, were described by Caliman et al. (2010).

The temporary ponds are located in the inner portion of the Restinga, where the sea influence is lower, and are primarily supplied with freshwater through rainfall and groundwater. The studied ponds are humic, small (approximately $60 \mathrm{~m}^{2}$ ), shallow and hydrologically isolated from other waterbodies. All temporary ponds are intensely colonized by aquatic macrophytes and surrounded by a shrub vegetation. Due to the high leaching of allochthonous dissolved organic carbon (DOC) from the permeable sandy soil, temporary ponds have high DOC concentrations (10-160 $\mathrm{mg} \mathrm{C}^{-1}$ ) and low $\mathrm{pH}$ values. These ponds can dry several times a year which makes their hydroperiod unpredictable. Therefore, samples were performed immediately after the beginning of the filling and during the period of hydrological variation.

\subsection{Sampling}

Zooplankton samples were collected three times in each environment. The samples were taken on April 6, April 10 and May 13, 2010. Temporary ponds were sampled at a central point and the permanent ones were sampled at a central and marginal points integrated in a single sample. Sampling consisted of $100 \mathrm{~L}$ of water collected with a bucket and filtered through a $50 \triangle \mathrm{m}$ mesh plankton net. Samples were immediately preserved in a $4 \%$ formalin solution. Zooplankton specimens were identified in the laboratory to the lowest taxonomic unit possible. Three subsamples were counted either in Sedgewick-Rafter cells under a microscope (for rotifers) and in open chambers under a stereomicroscope (for cladocerans and adult copepods). From the sample counts, we determined the species composition, richness and density of the zooplankton communities.

The environments were characterized in relation to depth, water total phosphorus (TP), Kjeldhal total nitrogen (TN), chlorophyll a (ChloA), pH, water temperature (Temp) and salinity (Sal). Limnological parameters were measured only in the first sampling. Temp and Sal were obtained in situ by automatic probes and water samples were taken to perform laboratory analyses. TP were obtained by molybdenum blue reaction, after persulphate oxidation (Golterman et al., 1978). ChloA content was determined by the method of Nusch \& Palmer (1975). TN content was determined by the method of Mackereth et al. (1978). pH was determined with an automatic probe.

\subsection{Functional diversity}

The functional traits considered in the functional diversity metrics were feeding preference, feeding mode, habitat preference and body size (Table 1). This set of traits were obtained from the literature, especially Koste (1978) and Elmoor-Loureiro (1997) and were chosen because they can be used to appraise how organisms are related to environmental conditions (Barnett \& Beisner, 2007; Litchman et al., 2013). The zooplankton functional diversity was described in terms of four metrics: functional dispersion (FDis) (Laliberté \& Legendre, 2010), functional richness (FRic), functional evenness (FEve) and functional divergence (FDiv) (Villéger et al., 2008). All indices represent distinct aspects of the variation in communities' functional traits and contribute to a better understanding of the ecological mechanisms that determine biodiversity. We used the Gower distance modified by Pavoine et al., (2009) wherein habitat was

Table 1. Zooplankton functional traits, type of trait and their respective classes used to calculate the functional indices.

\begin{tabular}{ccc}
\hline Trait & Type & Classes \\
\hline Trophic group & Physiological & $\begin{array}{c}\text { Herbivore; Omnivore; } \\
\text { Carnivore }\end{array}$ \\
$\begin{array}{c}\text { Feeding } \\
\text { mode }\end{array}$ & Behavioral & $\begin{array}{c}\text { Raptorial; Scraper; } \\
\text { Feeding-Current; } \\
\text { Suspensivore }\end{array}$ \\
Habitat & Behavioral & Coastal; Pelagic \\
Body size & Morphological & Quantitative \\
\hline
\end{tabular}


considered as a fuzzy trait, feeding type and trophic group as binary traits and body size as a quantitative trait. We used the maximum number of traits that allows the $S \geq 2^{\wedge} t$ condition to be met, where $S$ is the number of species and the number of traits. All indices were calculated using dbFD function from FD package (Laliberté \& Legendre, 2010) in $\mathrm{R}$ environment ( $\mathrm{R}$ Core Team, 2018).

To evaluate the zooplankton functional composition in each sample, the CWM (Community Weighted Mean value) for each functional trait was calculated as an average of traits values weighted by the species relative abundance. The CWM analysis of each trait allows us to evaluate the functional composition variability in different samples and thus provide answers about the community dynamics over time. The CWM values were obtained by the functcomp function of the FD package (Laliberté \& Legendre, 2010) in the R environment (R Core Team, 2018).

\subsection{Data analysis}

Permanent lagoons and temporary ponds were ordered regarding their limnological features through a principal component analysis (PCA). The function prcomp and biplot from stats package ( $\mathrm{R}$ Core Team, 2018) were used to perform the PCA in R environment (R Core Team, 2018). To compare the functional diversity of temporary and permanent environments and the sampling time effects, the values of FRic, FEve, FDiv, FDis and species richness $(S)$ were analyzed using a repeatedmeasure ANOVA (RM-ANOVA). This analysis was performed in $\mathrm{R}$ environment (R Core Team, 2018) through aov function from stats package (R Core Team, 2018). The respective graphs were made in GraphPad Prism 5 software (GraphPad, 2007).
To evaluate the similarity between the lagoons and ponds regarding their trait composition and expressiveness (abundance distribution among the different functional traits), we performed a PERMANOVA using CWM values calculated for all traits in each sample event. PERMANOVA was based on the Bray-Curtis distance with 999 permutations and performed in $\mathrm{R}$ environment through the adonis 2 function of the vegan package (Oksanen et al., 2018). We used the betadisper function from vegan package (Oksanen et al., 2018) to verify the average distance from each point to group centroid as a measure of multivariate dispersion. To verify significant differences in trait expressiveness among ponds and lagoons, we performed a permutation test for multivariate dispersions (PERMIDISP) through the permutest function from vegan package (Oksanen et al., 2018). Graphical representation of the functional structure was made by an NMDS also made in $\mathrm{R}$ environment using the functions metaNMDS and stressplot of the vegan package (Oksanen et al., 2018).

\section{Results}

Temporary ponds were characterized by depths less than $0.6 \mathrm{~m}$, low salinity and $\mathrm{pH}$ values and high values of TP, TN, ChloA and temperature (Table 2). The permanent lagoons, on the other hand, were characterized by depths between $0.6 \mathrm{~m}$ and $2.9 \mathrm{~m}$, with low concentration of TP, TN and ChloA (Table 2). PCA results illustrate the main features and the limnological differences of each type of environment (Figure 2). The two first axes explained $80 \%$ of the variation. Temporary environments are related to higher values of TP, TN and ChloA while permanent environments are related to high values

Table 2. Mean values of abiotic characteristics of ponds and lagoons located within Restinga de Jurubatiba National Park, Rio de Janeiro, Brazil: depth, temperature, salinity, $\mathrm{pH}$, chlorophyll- $a$ water concentration, water total nitrogen (NT) and water total phosphorus (TP).

\begin{tabular}{lccccccc}
\hline \multicolumn{1}{c}{ Ponds } & Depth $(\mathbf{m})$ & $\begin{array}{c}\text { Temperature } \\
\left({ }^{\circ} \mathbf{C}\right)\end{array}$ & $\begin{array}{c}\text { Salinity } \\
(\mathbf{p s u})\end{array}$ & $\mathbf{p H}$ & TP $\left(\boldsymbol{\mu m o l ~ \mathrm { I } ^ { - 1 } )}\right.$ & $\mathbf{T N}\left(\boldsymbol{\mu m o l ~ \mathbf { I } ^ { - 1 } )} \begin{array}{c}\text { Chlorophyll-a } \\
\left(\boldsymbol{\mu} \mathbf{g ~ I}^{-1}\right)\end{array}\right.$ \\
\hline Pond 01 & 0.5 & 27.8 & 0.0 & 4.3 & 0.80 & 58.50 & 9.60 \\
Pond 02 & 0.3 & 28.1 & 0.1 & 3.5 & 2.50 & 81.40 & ND \\
Pond 03 & 0.3 & 27.0 & 0.0 & 3.5 & 1.10 & 157.30 & 15.50 \\
Pond 04 & 0.3 & 33.4 & 0.3 & 3.6 & 2.30 & 191.20 & 22.00 \\
Pond 05 & 0.1 & 30.5 & 0.3 & 3.6 & 1.40 & 176.70 & 4.30 \\
Bezerra & 0.6 & 27.5 & 1.2 & 6.5 & 1.11 & 103.06 & 13.85 \\
Jurubatiba & 2.9 & 22.7 & 1.1 & 7.3 & 0.36 & 55.59 & 4.34 \\
Carapebus & 1.7 & 25.6 & 4.4 & 7.7 & 0.62 & 66.95 & 3.69 \\
Comprida & 2.0 & 22.7 & 0.4 & 5.5 & 0.53 & 64.53 & 2.27 \\
Paulista & 2.2 & 23.4 & 2.6 & 6.2 & 0.45 & 48.45 & 3.62 \\
\hline
\end{tabular}

$\mathrm{ND}=$ Not detected 


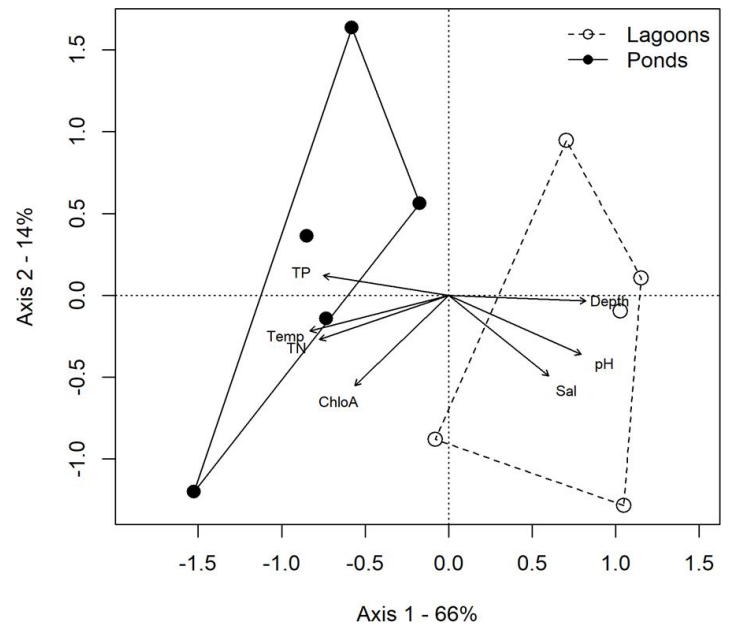

Figure 2. Principal Component Analysis (PCA) using limnological characteristics of temporary ponds and permanent lagoons located in Restinga de Jurubatiba National Park, Rio de Janeiro, Brazil. TP = Total phosphorus; $\mathrm{TN}=$ Total nitrogen; ChloA = Chloriphyll $\mathrm{a} ;$ Temp = Temperature; Sal = Salinity.

of salt, $\mathrm{pH}$ and depth. In addition, PCA showed a clear grouping for both temporary and permanent environments (Figure 2).

We found a total of 73 taxa in temporary and permanent environments. Of these, 38 taxa occurred exclusively in temporary environments and 5 species were found only in permanent environments (Table 3). Species richness was highest in Pond 4 (first sampling) and in Jurubatiba lagoon (second sampling), with 21 species recorded in both (Table 4). The values of functional diversity varied among sampling dates and types of environments, but the highest values were found in temporary environments for all functional indices (Table 4). The highest value of FRic was found in Pond 1 $(0.3695)$ in the third sampling. For FEve, the highest value was observed in Pond 3 in the first sampling (0.5662). The highest value of FDiv was found in Pond 2 during the third sampling (0.9842) and for FDis the highest value was found in Pond 5 also in the third sampling (0.4157). Functional diversity and species richness were not significantly different between temporary and permanent environments, except for FDis (RM-ANOVA, $\mathrm{F}=14.72, p=0.005$ ) in which temporary environments presented higher values than permanent ones (Figure 3).

The two types of environments were significantly different regarding the composition and abundance of functional traits in the first and third sampling (Table 5). In the first sampling, the temporary environments showed significantly higher functional expressiveness (greater distribution of points in the space of functional traits) than the permanent environments (Table 5, Figure 4A). In the second sampling, although the temporary environments still have a larger functional space representation, no significant differences were found between the two types of environments in terms of functional expressiveness (Figure 4B). In the third sampling, no significant differences were found, however permanent environments presented a larger functional space than the temporary environments. (Figure 4C). The zooplankton community from temporary environments was characterized by functional traits related to omnivorous and carnivorous trophic group, current-feeding and scraper feeding modes and coastal habitat. The zooplankton community from permanent environments was characterized by pelagic habitat, filter feeding mode and herbivorous feeding habit.

\section{Discussion}

Different studies have shown that permanent aquatic environments have greater or equal species richness when compared to equivalent temporary ones due to greater habitat stability (Araújo et al., 2013; Anton-Pardo et al., 2019). However, a growing number of studies have emphasized that temporary environments can be richer than permanent environments and emphasize the importance of these environments in regional scale (Boix et al., 2001; Meester et al., 2005; Hunter Junior et al., 2017). In our study, temporary and permanent environments are equally diverse in terms of species richness and functional diversity. However, the environments differ among them regarding the composition and expression of traits, revealing high functional complementarity. Our results demonstrated that both temporary and permanent environments are heterogeneous and diversified, especially the temporary ponds. Each temporary pond presents a unique and diversified set of species and functional traits. For the permanent lagoons, there is an overlapping in functional traits indicating the existence of a group of species that occurs in all environments of this type. Thus, because temporary and permanent environments harbor different species and, consequently, functional traits, the results obtained in this study indicate that lagoons and ponds are functionally complementary as predicted by our initial hypothesis.

Although the species richness was not different between ponds and lagoons, the total number of taxa that we found in temporary environments 
Table 3. Zooplankton species and their functional traits found in 5 temporary ponds and 5 permanent lagoons located in Restinga de Jurubatiba National Park, Rio de Janeiro, Brazil. Samples were taken in 6 and 20 April and 13 May 2010.

\begin{tabular}{|c|c|c|c|c|c|c|c|c|c|c|c|c|}
\hline \multirow[b]{2}{*}{ Taxa } & \multicolumn{2}{|c|}{ Environment } & \multirow[b]{2}{*}{$\begin{array}{c}\text { Body } \\
\text { size } \\
(\mathrm{mm})\end{array}$} & \multicolumn{2}{|c|}{ Habitat } & \multicolumn{4}{|c|}{ Feeding mode } & \multicolumn{3}{|c|}{$\begin{array}{c}\text { Trophic } \\
\text { group }\end{array}$} \\
\hline & 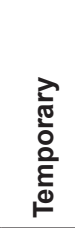 & 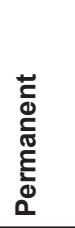 & & $\begin{array}{l}\bar{\pi} \\
0 \\
0 \\
0\end{array}$ & $\begin{array}{l}\frac{0}{9} \\
\frac{\pi}{0} \\
0\end{array}$ & 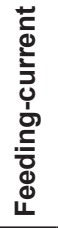 & 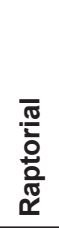 & 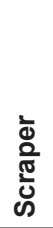 & $\begin{array}{l}0 \\
\frac{0}{0} \\
\frac{3}{\infty} \\
\frac{c}{0} \\
\frac{0}{0} \\
\stackrel{0}{D}\end{array}$ & 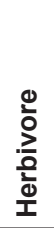 & 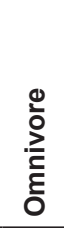 & 克 \\
\hline \multicolumn{13}{|l|}{ Rotifers } \\
\hline Ascomorpha ecaudis Perty, 1850 & 1 & 1 & 0.121 & 0 & 1 & 0 & 1 & 0 & 0 & 1 & 0 & 0 \\
\hline Bdelloidea & 1 & 0 & 0.127 & 0 & 1 & 1 & 0 & 0 & 1 & 0 & 1 & 0 \\
\hline Beauchampiella eudactylota (Gosse, 1886) & 1 & 1 & 0.211 & 1 & 0 & 1 & 0 & 0 & 0 & 1 & 0 & 0 \\
\hline Brachionus zahniseri Ahlstrom, 1934 & 0 & 1 & 0.287 & 1 & 0 & 1 & 0 & 0 & 0 & 1 & 0 & 0 \\
\hline Brachionus falcatus Lemmermann, 1908 & 0 & 1 & 0.128 & 0 & 1 & 1 & 0 & 0 & 0 & 1 & 0 & 0 \\
\hline Brachionus quadridentatus Hermann, 1783 & 1 & 0 & 0.287 & 1 & 0 & 1 & 0 & 0 & 0 & 1 & 0 & 0 \\
\hline Dicranophorus sp. & 1 & 0 & 0.322 & 1 & 0 & 0 & 1 & 0 & 0 & 0 & 0 & 1 \\
\hline Dipleuchlanis propatula (Gosse, 1886) & 1 & 1 & 0.182 & 1 & 0 & 1 & 0 & 0 & 0 & 1 & 0 & 0 \\
\hline Dissotrocha aculeata (Ehrenberg, 1832) & 1 & 0 & 0.127 & 0 & 1 & 0 & 0 & 0 & 0 & 0 & 1 & 0 \\
\hline Euchlanis sp. & 0 & 1 & 0.170 & 1 & 0 & 1 & 0 & 0 & 0 & 1 & 0 & 0 \\
\hline Filinia longiseta (Ehrenberg, 1834) & 1 & 0 & 0.133 & 0 & 1 & 1 & 0 & 0 & 0 & 0 & 1 & 0 \\
\hline Hexarthra mira (Hudson, 1871) & 1 & 1 & 0.191 & 0 & 1 & 1 & 0 & 0 & 0 & 1 & 0 & 0 \\
\hline Keratella Americana Carlin, 1943 & 1 & 0 & 0.166 & 0 & 1 & 1 & 0 & 0 & 0 & 1 & 0 & 0 \\
\hline Keratella lenzi (Hauer, 1953) & 1 & 0 & 0.146 & 0 & 1 & 1 & 0 & 0 & 0 & 1 & 0 & 0 \\
\hline Lecane boettgeri Koste, 1986 & 1 & 0 & 0.082 & 1 & 0 & 1 & 0 & 0 & 0 & 1 & 0 & 0 \\
\hline Lecane bulla (Gosse, 1851) & 1 & 1 & 0.122 & 1 & 0 & 1 & 0 & 0 & 0 & 1 & 0 & 0 \\
\hline Lecane cornuta (Müller, 1786) & 1 & 1 & 0.099 & 1 & 0 & 1 & 0 & 0 & 0 & 1 & 0 & 0 \\
\hline Lecane curvicornis (Murray, 1913) & 1 & 0 & 0.161 & 1 & 0 & 1 & 0 & 0 & 0 & 1 & 0 & 0 \\
\hline Lecane elegans Harring, 1914 & 1 & 0 & 0.175 & 1 & 0 & 1 & 0 & 0 & 0 & 1 & 0 & 0 \\
\hline Lecane eutarsa Harring \& Myers, 1926 & 1 & 1 & 0.092 & 1 & 0 & 1 & 0 & 0 & 0 & 1 & 0 & 0 \\
\hline Lecane furcata (Murray, 1913) & 1 & 0 & 0.175 & 1 & 0 & 1 & 0 & 0 & 0 & 1 & 0 & 0 \\
\hline Lecane hamata (Stokes, 1896) & 1 & 0 & 0.088 & 1 & 0 & 1 & 0 & 0 & 0 & 1 & 0 & 0 \\
\hline Lecane hornemanni (Ehrenberg, 1834) & 0 & 1 & 0.131 & 1 & 0 & 1 & 0 & 0 & 0 & 1 & 0 & 0 \\
\hline Lecane leontina (Turner, 1892) & 1 & 1 & 0.202 & 1 & 0 & 1 & 0 & 0 & 0 & 1 & 0 & 0 \\
\hline Lecane ludwigii (Eckstein, 1883) & 1 & 0 & 0.147 & 1 & 0 & 1 & 0 & 0 & 0 & 1 & 0 & 0 \\
\hline Lecane lunaris (Ehrenberg, 1832) & 1 & 1 & 0.135 & 1 & 0 & 1 & 0 & 0 & 0 & 1 & 0 & 0 \\
\hline Lecane monostyla (Daday, 1897) & 1 & 0 & 0.071 & 1 & 0 & 1 & 0 & 0 & 0 & 1 & 0 & 0 \\
\hline Lecane proiecta Hauer, 1956 & 1 & 0 & 0.153 & 1 & 0 & 1 & 0 & 0 & 0 & 1 & 0 & 0 \\
\hline Lecane pyriformis (Daday, 1905) & 1 & 0 & 0.094 & 1 & 0 & 1 & 0 & 0 & 0 & 1 & 0 & 0 \\
\hline Lecane quadridentata (Ehrenberg, 1830) & 1 & 0 & 0.135 & 1 & 0 & 1 & 0 & 0 & 0 & 1 & 0 & 0 \\
\hline Lecane signifera (Jennings, 1896) & 1 & 0 & 0.113 & 1 & 0 & 1 & 0 & 0 & 0 & 1 & 0 & 0 \\
\hline Lecane stenroosi (Meissner, 1908) & 1 & 1 & 0.092 & 1 & 0 & 1 & 0 & 0 & 0 & 1 & 0 & 0 \\
\hline Lecane stichaea Harring, 1913 & 1 & 0 & 0.086 & 1 & 0 & 1 & 0 & 0 & 0 & 1 & 0 & 0 \\
\hline Lepadella patella (Müller, 1773) & 1 & 1 & 0.123 & 1 & 0 & 1 & 0 & 0 & 0 & 1 & 0 & 0 \\
\hline Macrochaetus longipes Myers, 1934 & 1 & 0 & 0.114 & 1 & 0 & 1 & 0 & 0 & 0 & 1 & 0 & 0 \\
\hline Monommata sp. & 1 & 0 & 0.161 & 1 & 0 & 0 & 1 & 0 & 0 & 0 & 1 & 0 \\
\hline Mytilina macrocera (Jennings, 1894) & 1 & 1 & 0.320 & 1 & 0 & 1 & 0 & 0 & 0 & 1 & 0 & 0 \\
\hline Platyas quadricornis (Ehrenberg, 1832) & 1 & 0 & 0.273 & 1 & 0 & 1 & 0 & 0 & 0 & 1 & 0 & 0 \\
\hline Polyarthra dolichoptera Idelson, 1925 & 1 & 1 & 0.111 & 0 & 1 & 0 & 1 & 0 & 0 & 1 & 0 & 0 \\
\hline Testudinella patina (Hermann, 1783) & 1 & 1 & 0.190 & 1 & 0 & 1 & 0 & 0 & 0 & 0 & 0 & 1 \\
\hline Trichocerca bicristata (Gosse, 1887) & 1 & 1 & 0.243 & 0 & 1 & 0 & 1 & 0 & 0 & 1 & 0 & 0 \\
\hline \multicolumn{13}{|l|}{ Cladocerans } \\
\hline Alonella clathratula Sars, 1896 & 1 & 0 & 0.450 & 1 & 0 & 0 & 0 & 1 & 0 & 1 & 0 & 0 \\
\hline Alonella sp. & 1 & 0 & 0.285 & 1 & 0 & 0 & 0 & 1 & 0 & 1 & 0 & 0 \\
\hline Anthalona verrucosa (Sars, 1901) & 1 & 1 & 0.301 & 1 & 0 & 0 & 0 & 1 & 0 & 1 & 0 & 0 \\
\hline Bosminopsis deitersi Richard, 1895 & 1 & 1 & 0.238 & 0 & 1 & 1 & 0 & 0 & 0 & 1 & 0 & 0 \\
\hline Camptocercus australis Sars, 1896 & 1 & 0 & 0.680 & 1 & 0 & 0 & 0 & 1 & 0 & 1 & 0 & 0 \\
\hline
\end{tabular}


Table 3. Continued...

\begin{tabular}{|c|c|c|c|c|c|c|c|c|c|c|c|c|}
\hline \multirow[b]{2}{*}{ Taxa } & \multicolumn{2}{|c|}{ Environment } & \multirow[b]{2}{*}{$\begin{array}{c}\text { Body } \\
\text { size } \\
(\mathrm{mm})\end{array}$} & \multicolumn{2}{|c|}{ Habitat } & \multicolumn{4}{|c|}{ Feeding mode } & \multicolumn{3}{|c|}{$\begin{array}{l}\text { Trophic } \\
\text { group }\end{array}$} \\
\hline & 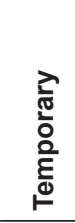 & 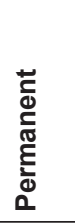 & & $\begin{array}{l}\bar{\pi} \\
\text { 总 } \\
\text { O }\end{array}$ & $\begin{array}{l}\frac{0}{0} \\
\frac{\pi}{0} \\
0\end{array}$ & 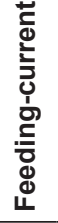 & 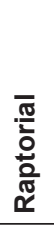 & $\begin{array}{l}\frac{1}{0} \\
\frac{0}{\pi} \\
\frac{0}{U}\end{array}$ & $\begin{array}{l}0 \\
\frac{0}{0} \\
\stackrel{2}{\infty} \\
\frac{c}{0} \\
\frac{0}{0} \\
\stackrel{0}{D}\end{array}$ & 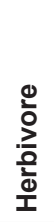 & 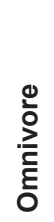 & 을 \\
\hline Ceriodaphnia cornuta Sars, 1885 & 1 & 1 & 0.334 & 0 & 1 & 1 & 0 & 0 & 0 & 1 & 0 & 0 \\
\hline Coronatella monocantha (Sars, 1901) & 1 & 0 & 0.347 & 1 & 0 & 0 & 0 & 1 & 0 & 1 & 0 & 0 \\
\hline Chydorus eurinotus Sars, 1901 & 1 & 1 & 0.298 & 1 & 0 & 0 & 0 & 1 & 0 & 1 & 0 & 0 \\
\hline Chydorus pubescens Sars, 1901 & 1 & 1 & 0.298 & 1 & 0 & 0 & 0 & 1 & 0 & 1 & 0 & 0 \\
\hline Diaphanosoma birgei Korínek, 1981 & 1 & 1 & 0.687 & 0 & 1 & 1 & 0 & 0 & 0 & 1 & 0 & 0 \\
\hline Diaphanosoma spinulosum Herbst 1975 & 1 & 0 & 0.530 & 0 & 1 & 1 & 0 & 0 & 0 & 1 & 0 & 0 \\
\hline Disparalona hamata (Birge, 1879) & 1 & 0 & 0.504 & 1 & 0 & 0 & 0 & 1 & 0 & 1 & 0 & 0 \\
\hline Dunhevedia crassa King, 1853 & 0 & 1 & 0.550 & 1 & 0 & 0 & 0 & 1 & 0 & 1 & 0 & 0 \\
\hline Dunhevedia odontoplax Sars, 1901 & 1 & 0 & 0.406 & 1 & 0 & 0 & 0 & 1 & 0 & 1 & 0 & 0 \\
\hline Ephemeroporus barroisi (Richard 1894) & 1 & 1 & 0.237 & 1 & 0 & 0 & 0 & 1 & 0 & 1 & 0 & 0 \\
\hline Ephemeroporus hybridus (Daday 1905) & 1 & 0 & 0.279 & 1 & 0 & 0 & 0 & 1 & 0 & 1 & 0 & 0 \\
\hline $\begin{array}{l}\text { Euryalona brasiliensis Brehm \& Thomsen, } \\
1936\end{array}$ & 1 & 0 & 0.554 & 1 & 0 & 0 & 0 & 1 & 0 & 1 & 0 & 0 \\
\hline Graptoleberis occidentalis Sars, 1901 & 1 & 1 & 0.525 & 1 & 0 & 0 & 0 & 1 & 0 & 1 & 0 & 0 \\
\hline Ilyocriptus spinifer Herrick, 1882 & 1 & 1 & 0.523 & 1 & 0 & 1 & 0 & 0 & 0 & 1 & 0 & 0 \\
\hline Latonopsis australis Sars, 1888 & 1 & 0 & 1.039 & 1 & 0 & 1 & 0 & 0 & 0 & 1 & 0 & 0 \\
\hline Macrothrix mira Smirnov, 1982 & 1 & 0 & 0.375 & 1 & 0 & 1 & 0 & 1 & 0 & 1 & 0 & 0 \\
\hline Macrothrix elegans Sars, 1901 & 1 & 0 & 0.506 & 1 & 0 & 0 & 0 & 1 & 0 & 1 & 0 & 0 \\
\hline Macrothrix spinosa King 1853 & 1 & 0 & 0.499 & 1 & 0 & 1 & 0 & 1 & 0 & 1 & 0 & 0 \\
\hline Magnospina dentifera (Sars 1901) & 1 & 0 & 0.381 & 1 & 0 & 0 & 0 & 1 & 0 & 1 & 0 & 0 \\
\hline Moina minuta Hansen, 1899 & 1 & 1 & 0.449 & 0 & 1 & 1 & 0 & 0 & 0 & 1 & 0 & 0 \\
\hline Notoalona sculpta (Sars, 1901) & 1 & 1 & 0.420 & 1 & 0 & 0 & 0 & 1 & 0 & 1 & 0 & 0 \\
\hline Pseudosida ramosa Daday, 1904 & 1 & 1 & 0.845 & 1 & 0 & 1 & 0 & 0 & 0 & 1 & 0 & 0 \\
\hline $\begin{array}{l}\text { Scapholeberis armata Dumont \& } \\
\text { Pensaert, } 1983\end{array}$ & 1 & 0 & 0.418 & 0 & 1 & 1 & 0 & 0 & 0 & 1 & 0 & 0 \\
\hline $\begin{array}{l}\text { Simocephalus latirostris Stingelin, } 1906 \\
\text { Copepods }\end{array}$ & 1 & 1 & 0.731 & 0 & 1 & 1 & 0 & 0 & 0 & 1 & 0 & 0 \\
\hline Diaptomus azureus Reid 1985 & 1 & 1 & 0.740 & 0 & 1 & 1 & 0 & 0 & 1 & 1 & 0 & 0 \\
\hline Microcyclops sp. & 1 & 0 & 0.695 & 0 & 0 & 0 & 1 & 0 & 0 & 0 & 0 & 1 \\
\hline Notodiaptomus cearensis Wright 1936 & 1 & 1 & 0.800 & 0 & 1 & 1 & 0 & 0 & 1 & 1 & 0 & 0 \\
\hline
\end{tabular}

was twice that found in permanent environments. Several factors can influence the occurrence of species in a given location, which include the tolerance of organisms to environmental conditions, interactions between species and their dispersal capacity (Declerck et al., 2011; Lopes et al., 2016; Seminara et al., 2008). In the case of zooplankton, previous studies have shown that local factors (environmental conditions and species interactions) play a major role in community structuring since differences in dispersal capacity are less relevant in promoting differences between nearby aquatic environments (Shurin et al., 2000; Lopes et al., 2016), as in the case of the environments studied here. Although we have not directly measured the dispersal of organisms, previous studies using ponds in the same region have shown that dispersal is not a limiting factor, at least in the studied scale, for the occurrence of zooplankton species (Araújo et al., 2015; Lopes et al., 2016). Therefore, we believe that communities of both temporary and permanent environments are primarily structured by local conditions and species interactions.

Among the main local factors that influence the occurrence of species, salinity may play an important role on structuring zooplankton communities in coastal systems by modifying their structure and dynamics (de Macedo-Soares et al., 2010; Santangelo et al., 2008). In shallow coastal lagoons, salinity may increase due to changes in rainfall patterns, marine influence and sandbar openings (Esteves et al., 2008). Salinization is recognized 
Table 4. Data of Richness (S), Functional Richness (FRic), Functional Evenness (FEve), Functional Divergence (FDiv) and Functional Dispersion (FDis) observed in the temporary ponds and permanent lagoons located within Restinga de Jurubatiba National Park, Rio de Janeiro, Brazil. Samples were taken in 6 and 20 of April and 13 of May 2010, respectively.

\begin{tabular}{llccccc}
\hline \multicolumn{1}{c}{ First Sampling } & S & FRic & FEve & FDiv & FDis \\
& Jurubatiba & 10 & 0.168764 & 0.322926 & 0.475706 & 0.262300 \\
& Bezerra & 10 & 0.228233 & 0.284292 & 0.815744 & 0.243559 \\
& Carapebus & 19 & 0.323902 & 0.301727 & 0.930192 & 0.118707 \\
& Comprida & 20 & 0.303732 & 0.429913 & 0.982643 & 0.144106 \\
& Paulista & 9 & 0.274196 & 0.251335 & 0.715914 & 0.146380 \\
& Pond 1 & 11 & 0.224756 & 0.485513 & 0.982285 & 0.196884 \\
& Pond 2 & 16 & 0.271090 & 0.233274 & 0.898572 & 0.290456 \\
& Pond 3 & 10 & 0.293397 & 0.560173 & 0.784826 & 0.376439 \\
Second & Pond 4 & 21 & 0.303976 & 0.163837 & 0.873316 & 0.366523 \\
& Pond 5 & 12 & 0.264070 & 0.273013 & 0.954668 & 0.220858 \\
& Jurubatiba & 21 & 0.357075 & 0.466717 & 0.959598 & 0.197298 \\
& Bezerra & 14 & 0.281412 & 0.393542 & 0.983917 & 0.050692 \\
& Carapebus & 9 & 0.225455 & 0.307165 & 0.655155 & 0.031826 \\
& Comprida & 17 & 0.255037 & 0.482911 & 0.840007 & 0.294095 \\
& Paulista & 17 & 0.309505 & 0.313594 & 0.827882 & 0.063175 \\
& Pond 1 & 12 & 0.218015 & 0.386663 & 0.939234 & 0.299653 \\
& Pond 2 & 2 & 0 & 0 & 0 & 0.089856 \\
& Pond 3 & 20 & 0.307245 & 0.242854 & 0.880899 & 0.393623 \\
& Pond 4 & 16 & 0.238696 & 0.272640 & 0.753547 & 0.390391 \\
& Pond 5 & 12 & 0.298272 & 0.417264 & 0.892876 & 0.332094 \\
Third Sampling & Jurubatiba & 12 & 0.274954 & 0.393720 & 0.917297 & 0.072419 \\
& Bezerra & 11 & 0.195229 & 0.233085 & 0.901910 & 0.229032 \\
& Carapebus & 10 & 0.231451 & 0.361907 & 0.426178 & 0.095495 \\
& Comprida & 20 & 0.246030 & 0.407609 & 0.735619 & 0.366732 \\
& Paulista & 7 & 0.051615 & 0.456921 & 0.769085 & 0.084524 \\
& Pond 1 & 13 & 0.369491 & 0.496865 & 0.867281 & 0.361740 \\
& Pond 2 & 13 & 0.210833 & 0.298387 & 0.984259 & 0.355984 \\
& Pond 3 & 18 & 0.256863 & 0.395454 & 0.845504 & 0.365964 \\
& Pond 4 & 14 & 0.263301 & 0.229407 & 0.981560 & 0.386913 \\
& Pond 5 & 20 & 0.303168 & 0.417162 & 0.887865 & 0.415677 \\
\hline \multirow{5}{*}{ Sand } & & & & &
\end{tabular}

Table 5. PERMANOVA F and $\mathrm{p}$ values based on Bray-Curtis distance for functional composition (CWM values for functional traits related to feeding mode, trophic group, habitat and body size) and statistic parameters of Permutation test for homogeneity of multivariate dispersions (PERMIDISP) based on PERMANOVA for functional composition. Numbers in bold mean significant values. In both tests 999 permutations were made.

\begin{tabular}{|c|c|c|c|c|c|c|}
\hline \multirow{2}{*}{ PERMANOVA } & \multicolumn{2}{|c|}{ Sampling 1} & \multicolumn{2}{|c|}{ Sampling 2} & \multicolumn{2}{|c|}{ Sampling 3} \\
\hline & $\mathbf{F}$ & $p$ & $\mathbf{F}$ & $p$ & $F$ & $p$ \\
\hline Type of environment & 7.93 & 0.01 & 2.11 & 0.11 & 5.23 & 0.02 \\
\hline PERMIDISP & $\mathrm{F}$ & $\mathrm{p}$ & $\mathrm{F}$ & $\mathrm{p}$ & $\mathrm{F}$ & $\mathrm{P}$ \\
\hline Functional diversity & 3.64 & 0.05 & 0.01 & 0.93 & 1.28 & 0.31 \\
\hline
\end{tabular}

for its negative effects on freshwater environments, e.g. reducing biodiversity and modifying species dominance patterns, population dynamics and trophic chain structure (Santangelo et al., 2013, 2008; Araújo et al., 2015; Castillo et al., 2018). Among the environments evaluated here, coastal lagoons showed the highest salinity values. Due to their location close to the sea, these environments are strongly influenced by marine spray and are subject to sandbar openings whose effects on species richness and composition are widely studied (Setubal et al., 2013; Santangelo et al., 2007; Branco et al., 2008; Esteves et al., 2008). Therefore, the lower number of taxa found in permanent lagoons may be associated with the elevated salinity values found in these environments.

The greater diversity found in temporary environments has been associated to the short-term 

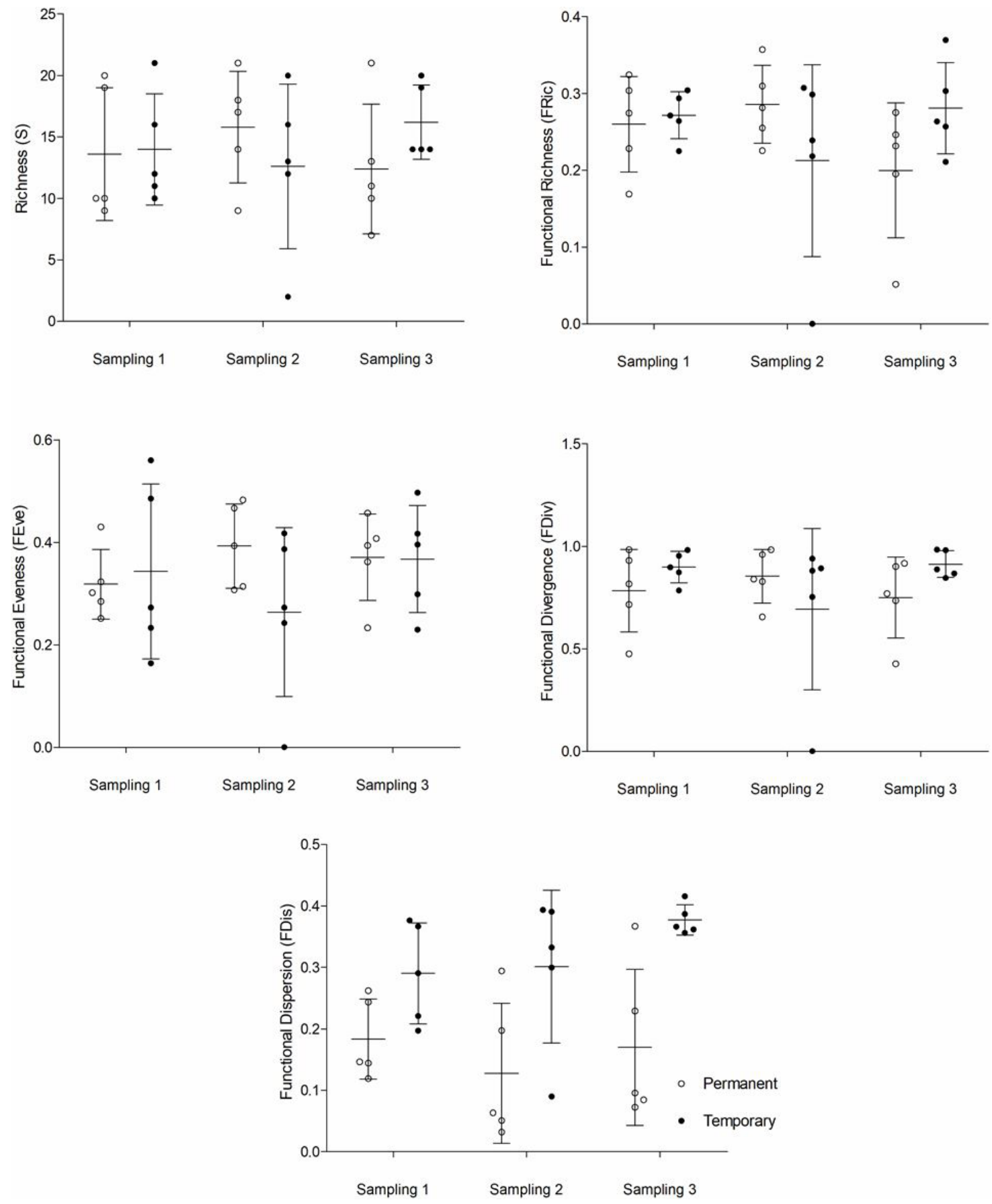

Figure 3. Values of Functional Evenness (FEve), Functional Richness (FRic), Functional Divergence (FDiv), Richness (S) and Functional Dispersion (FDis) for temporary ponds and permanent lagoons located in Restinga de Jurubatiba National Park, Rio de Janeiro, Brazil. Significant difference was found between temporary and permanent environments for FDis (RM-ANOVA, F=14.72, $p=0.005$ ). The samples were collected in 6 and 20 of April and 13 of May 2010.

variation to which these environments are submitted (Serrano \& Fahd, 2005; Powell \& Babbitt, 2016; Schriever et al., 2014; Brendonck et al., 2017). The occurrence of a dry phase requires temporary environments to restart the successional trajectory of their aquatic communities and even if the abiotic conditions are the same for all environments located in the same region, this type of disturbance can produce different patterns of species composition (Fukami et al., 2005). On the other hand, in less variable environments, such as permanent lagoons, there is a well-established community composed by species adapted to local conditions and the effects of the arrival of new species on the resident 

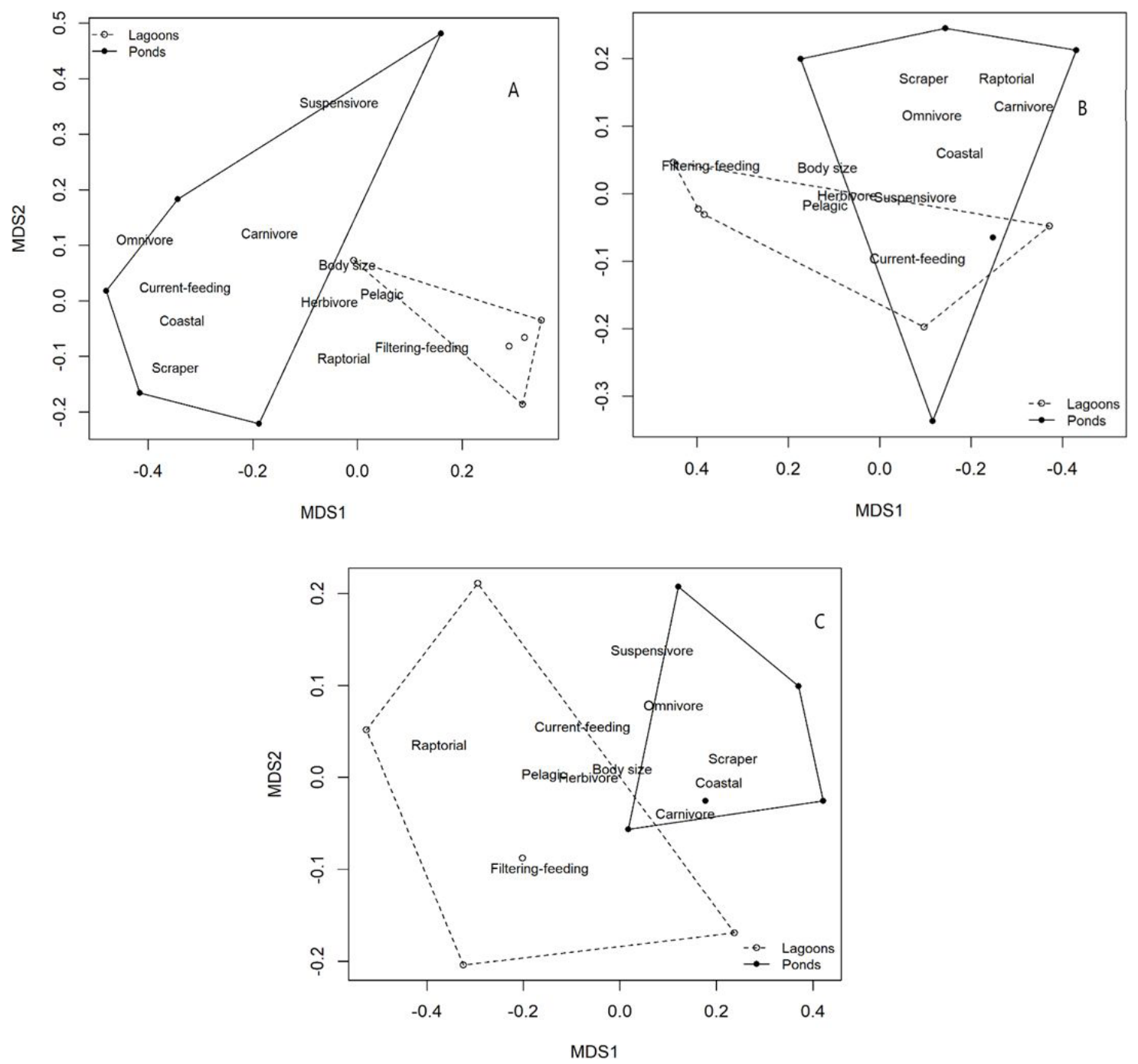

Figure 4. Multidimensional non-metric scaling (nMDS) considering the CWM values of the functional traits of the zooplankton community observed in temporary ponds and permanent lagoons located in Restinga de Jurubatiba National Park, Rio de Janeiro, Brazil. (A) First sampling; (B) Second sampling; (C) Third sampling.

community are minimal given their low biomass (Shurin, 2000). Thus, since coastal lagoons are similar regarding their limnological characteristics and less variable over time, zooplankton community tends to be similar among this type of environments. In contrast, at each seasonal cycle of filling in temporary environments, stochastic and priority effects on the arrival and establishment of organisms (Jenkins \& Buikema Junior, 1998; Scheffer et al., 2006) can make that each pond have a unique and differentiated successional trajectory and community composition.

Even though stochastic events and differences in dispersal strategies can make the establishment of the zooplankton community unpredictable, temporary environments can present resident species from a well-established egg bank (Declerck et al., 2011;
Vanschoenwinkel et al., 2009). However, speciesspecific differences in hatching time, number of hatches during the wet phase and abundance and diversity of the egg bank also influence the structure of the active community (Jocque et al., 2010; Brendonck et al., 2017; Pinceel et al., 2018, 2017). In addition, even if a large number of eggs of a certain species hatch, their success of establishment depends on ecological relationships with the other species that colonized the environment by dispersal and the environmental conditions at the hatching moment (Declerck et al., 2011; Brendonck et al., 2017; Pinceel et al., 2018). Therefore, unsaturated and heterogeneous environments such as temporary ponds can present a wide variety of species combinations and can function as small refuges of 
species that do not arrive or develop in more stable environments such as lagoons.

Regarding functional diversity, lagoons and ponds differ only in relation to functional dispersion. This index represents the average distance of the species to the centroid of the group in a multidimensional space of functional traits weighted by the abundance of the species (Laliberté \& Legendre, 2010). Higher values of FDis are found when functionally distinct traits are present with similar abundances (Frainer et al., 2014). Thus, even if no significant differences were found for functional richness, the high values of FDis observed in the temporary ponds demonstrate the greater variability and functional complementarity of the communities in these environments. Similarly, Massicotte et al. (2014) found greater functional variability of zooplankton in heterogeneous environments. It can be explained by the fact that temporal instability facilitates the coexistence of species by reducing the probability that few species with certain traits competitively exclude the others (Connell, 1978). Therefore, in the case of environments such as temporary ponds, temporal instability may act as a promoter of the functional variability of natural communities on a regional scale.

Temporary environments, although they occupy a small area, can present a wide variety of habitat structure and variability in their limnological characteristics. For example, the temporary environments evaluated in this study showed an amplitude of variation in nutrient content (TP, TN), ChloA and temperature higher than permanent ponds, even with higher values. The results obtained with PCA demonstrate a clear differentiation of the two types of environments regarding their limnological characteristics, which also reflected in the composition and distribution of functional traits. Limnological conditions usually act favoring the establishment of species with functional traits that confer an adaptive advantage to such conditions (Drenner et al., 2009). For example, considering that the temporary environment studied here presented low depth, high coverage of macrophytes and a great amount of material in suspension, the greater expression of traits related to the omnivorous habit, scraper and suspensivore feeding mode and the coastal habitat indicate that ecological filters favor species particularly well adapted to the unique conditions of temporary environments (Seminara et al., 2008). On the other hand, the zooplankton community from permanent environment was characterized by the pelagic habitat, filter feeding mode and herbivorous feeding preference in accordance with the limnological characteristics of these environments.

Considering complementarity as the property of two groups of objects, in our case environments, which contemplate different sets of characteristics (Williams, 2011), our results showed that in relation to the limnological characteristics as well as the zooplankton functional diversity, temporary and permanent environments are complementary to each other. Even though no significant differences were found in terms of taxonomic and functional richness, zooplankton in both environments presented unique and, therefore, complementary characteristics. Our results illustrate how small, temporary, and historically neglected environments can harbor a biological diversity that is still poorly understood, such as functional trait diversity. In this sense, this study points to the need for greater protection of small wetlands, especially temporary ones, given their importance in sheltering a portion of biological diversity not found in other environments (Hunter Junior et al., 2017; Calhoun et al., 2017; Mullins \& Doyle, 2019).

\section{Conclusions}

Temporary and permanent environments present functional complementarity that makes them important to maintain the functional diversity on a regional scale. Temporary environments can function as small refuges of species that do not arrive or develop in more stable environments because these species are more likely to colonize environments that are periodically restarting their successional trajectory. Therefore, temporary ponds are especially important because of their unique characteristics and their role in metacommunity dynamics as well as valuable resources for evolutionary and ecological research that focuses on ecosystem services (Meester et al., 2005; Calhoun et al., 2017; Bozelli et al., 2018). However, those environments have been exposed to a variety of impacts such as changes in dry phase frequency and duration (as a result of climate changes), salinization, exotic species introduction, as well as other effects, which are ultimately imposing them major habitat degradations and biodiversity extinction. Consequently, actions that seek to preserve ponds are essential and urgent, especially directed to those smaller and more fragile environments located in regions of intense anthropogenic pressure. 


\section{Acknowledgements}

We thank the staff of the Laboratorio de Limnologia of Universidade Federal do Rio de Janeiro - UFRJ and Instituto de Biodiversidade e Sustentabilidade de Macaé - NUPEM for both field and laboratory assistance, and Instituto Chico Mendes de Conservação da Biodiversidade - ICMBio for field assistance in Jurubatiba National Park. We thank Rodrigo Araújo do Nascimento who made the map used in this study. Financial support and grants were provided by Coordenação de Aperfeiçoamento de Pessoal de Nível Superior - CAPES, Conselho Nacional de Desenvolvimento Científico e Tecnológico - CNPq (Proc. 476759/2009-9, Proc. 306105/2014-4 and 303778/2010-5) and Fundação de Amparo à Pesquisa do Estado do Rio de Janeiro - Faperj.

\section{References}

AL-THAWADI, S. Microplastics and nanoplastics in aquatic environments: challenges and threats to aquatic organisms. Arabian Journal for Science and Engineering, 2020, 45(6), 4419-4440. http://dx.doi. org/10.1007/s13369-020-04402-z.

ANTON-PARDO, M., ORTEGA, J.C.G., MELO, A.S. and BINI, L.M. Global meta-analysis reveals that invertebrate diversity is higher in permanent than in temporary lentic water bodies. Freshwater Biology, 2019, 64(12), 2234-2246. http://dx.doi. org/10.1111/fwb.13409.

ARAÚJO, L., LOPES, P.M., SANTANGELO, J.M., PETRY, A.C. and BOZELLI, R.L. Zooplankton resting egg banks in permanent and temporary tropical aquatic systems. Acta Limnologica Brasiliensia, 2013, 25(3), 235-245. http://dx.doi.org/10.1590/ S2179-975X2013000300004.

ARAÚJO, L.R., LOPES, P.M., SANTANGELO, J.M., ESTEVES, F.A. and BOZELLI, R.L. Long-term dynamics of the zooplankton community during large salinity fluctuations in a coastal lagoon. Marine and Freshwater Research, 2015, 66(4), 352-359. http://dx.doi.org/10.1071/MF14083.

BARNETT, A.J. and BEISNER, B.E. Zooplankton biodiversity and lake trophic state: explanations invoking resource abundance and distribution. Ecology, 2007, 88(7), 1675-1686. http://dx.doi. org/10.1890/06-1056.1. PMid:17645014.

BIGGS, J., VON FUMETTI, S. and KELLY-QUINN, M. The importance of small waterbodies for biodiversity and ecosystem services: implications for policy makers. Hydrobiologia, 2017, 793(1), 3-39. http://dx.doi.org/10.1007/s10750-016-3007-0.

BOIX, D., SALA, J. and MORENO-AMICH, R. The faunal composition of espolla pond (NE Iberian Peninsula): The neglected biodiversity of temporary waters. Wetlands, 2001, 21(4), 577-592. http:// dx.doi.org/10.1672/0277-5212(2001)021[0577:TF COEP]2.0.CO;2.

BOZELLI, R.L., FARIAS, D.S., LIMA, S.K.F., LIRA, R.T.S., NOVA, C.C., SETUBAL, R.B. and SODRÉ, E.O. Pequenas áreas úmidas: importância para conservação e gestão da biodiversidade brasileira. Biodiversidade e Gestão, 2018, 2(2), 122-138.

BRANCO, C.C., KOZLOWSKY-SUZUKI, B., ESTEVES, F.A. and AGUIARO, T. Zooplankton distribution and community structure in a Brazilian coastal lagoon. Vie et Milieu-Life and Environment, 2008, 58(1), 1-9.

BRENDONCK, L., PINCEEL, T. and ORTELLS, R. Dormancy and dispersal as mediators of zooplankton population and community dynamics along a hydrological disturbance gradient in inland temporary Ponds. Hydrobiologia, 2017, 796(1), 201 222. http://dx.doi.org/10.1007/s10750-016-3006-1.

BURKEPILE, D.E. and HAY, M.E. Feeding complementarity versus redundancy among herbivorous fishes on a Caribbean reef. Coral Reefs, 2011, 30(2), 351-362. http://dx.doi.org/10.1007/ s00338-011-0726-6.

CALHOUN, A.J.K., MUSHET, D.M., BELL, K.P., BOIX, D., FITZSIMONS, J.A. and ISSELINNONDEDEU, F. Temporary wetlands: challenges and solutions to conserving a 'disappearing' ecosystem. Biological Conservation, 2017, 211, 3-11. http://dx.doi.org/10.1016/j.biocon.2016.11.024.

CALIMAN, A., CARNEIRO, L.S., SANTANGELO, J.M., GUARIENTO, R.D., PIRES, A.P.F., SUHETT, A.L., QUESADO, L.B., SCOFIELD, V., FONTE, E.S., LOPES, P.M., SANCHES, L.F., AZEVEDO, F.D., MARINHO, C.C., BOZELLI, R.L., ESTEVES, F.A. and FARJALLA, V.F. Temporal coherence among tropical coastal lagoons: a search for patterns and mechanisms. Brazilian Journal of Biology = Revista Brasileira de Biologia, 2010, 70(3, Suppl.), 803-814. http://dx.doi.org/10.1590/S151969842010000400011 . PMid:21085785.

CASTILLO, A.M., SHARPE, D.M.T., GHALAMBOR, C.K. and DE LEÓN, L.F. Exploring the effects of salinization on trophic diversity in freshwater ecosystems: a quantitative review. Hydrobiologia, 2018, 807(1), 1-17. http://dx.doi.org/10.1007/ s10750-017-3403-0.

CONNELL, J.H. Diversity in tropical rain forests and coral reefs. Science, 1978, 199(4335), 1302-1310. http://dx.doi.org/10.1126/science.199.4335.1302. PMid:17840770.

DAY, J.W. and RYBCZYK, J.M. Global change impacts on the future of coastal systems: perverse interactions among climate change, ecosystem degradation, energy scarcity, and population. In: E. WOLANSKI, J.W. DAY, M. ELLIOT and R. RAMACHANDRAN, eds. Coasts and estuaries: the 
future. New York: Elsevier, 2019, pp. 621-639. http:// dx.doi.org/10.1016/B978-0-12-814003-1.00036-8.

DECLERCK, S., CORONEL, J.S., LEGENDRE, P. and BRENDONCK, L. Scale dependency of processes structuring metacommunities of cladocerans in temporary Ponds of High-Andes wetlands. Ecography, 2011, 34(2), 296-305. http:// dx.doi.org/10.1111/j.1600-0587.2010.06462.x.

DRENNER, S.M., DODSON, S.I., DRENNER, R.W. and PINDER III, J.E. Crustacean zooplankton community structure in temporary and permanent grassland ponds. Hydrobiologia, 2009, 632(1), 225233. http://dx.doi.org/10.1007/s10750-009-9843-4.

ELMOOR-LOUREIRO, L.M.A. Manual de identificação de cladóceros Limnicos do Brasil. Brasilia:Editora Universa, 1997.

ELMQVisT, T., FOLKE, C., NYSTRÖM, M., PETERSON, G., BENGTSSON, J., WALKER, B. and NORBERG, J. Response diversity, ecosystem change, and resilience. Frontiers in Ecology and the Environment, 2003, 1(9), 488-494. http://dx.doi. org/10.1890/1540-9295(2003)001[0488:RDECA R]2.0.CO;2.

ESTEVES, F.A., CALIMAN, A., SANTANGELO, J.M., GUARIENTO, R.D., FARJALLA, V.F. and BOZELLI, R.L. Neotropical coastal lagoons: an appraisal of their biodiversity, functioning, threats and conservation management. Brazilian Journal of Biology $=$ Revista Brasileira de Biologia, 2008, 68(4, Suppl.), 967-981. http://dx.doi.org/10.1590/S151969842008000500006. PMid:19197469.

FONSECA, B.M., DE MENDONÇA-GALVÃO, L., SOUSA, F.D.R., ELMOOR-LOUREIRO, L.M.A., GOMES-E-SOUZA, M.B., PINTO, R.L., PETRACCO, P., OLIVEIRA, R.C. and JESUS LIMA, E. Biodiversity in pristine wetlands of Central Brazil: a multi-taxonomic approach. Wetlands, 2018, 38(1), 145-156. http://dx.doi.org/10.1007/s13157017-0964-7.

FRAINER, A., MCKIE, B.G. and MALMQVIST, B. When does diversity matter? Species functional diversity and ecosystem functioning across habitats and seasons in a field experiment. Journal of Animal Ecology, 2014, 83(2), 460-469. http://dx.doi. org/10.1111/1365-2656.12142. PMid:26046457.

FUKAMI, T., MARTIJN BEZEMER, T., MORTIMER, S.R. and PUTTEN, W.H. Species divergence and trait convergence in experimental plant community assembly. Ecology Letters, 2005, 8(12), 1283-1290. http://dx.doi.org/10.1111/j.14610248.2005.00829.x.

GESSNER, M.O., INCHAUSTI, P., PERSSON, L., RAFFAELLI, D.G. and GILLER, P.S. Biodiversity effects on ecosystem functioning: insights from aquatic systems. Oikos, 2004, 104, 419-422. http:// dx.doi.org/10.1111/j.0030-1299.1999.13252.x.
GOLTERMAN, H.L., CLIMO, R.S. and OHNSTAD, M.A.M. Methods for physical and chemical analysis of freshwaters. Oxford: Blackwell Scientific Publications, 1978. I.B.P. Handbook, no. 8.

GOZLAN, R.E., KARIMOV, B.K., ZADEREEV, E., KUZNETSOVA, D. and BRUCET, S. Status, trends, and future dynamics of freshwater ecosystems in Europe and Central Asia. Inland Waters, 2019, 9(1), 78-94. http://dx.doi.org/10.1080/20442041. 2018.1510271.

GRAPHPAD. Graphpad Prism 5 for Windows. Version 5.01. San Diego, 2007.

HUMBERT, J.F. and DORIGO, U. Biodiversity and aquatic ecosystem functioning: a mini-review. Aquatic Ecosystem Health \& Management, 2005, 8(4), 367-374. http://dx.doi.org/10.1080/14634980500457773.

HUNTER JUNIOR, M.L., ACUNAA, V., BAUER, D.M., BELL, K.P., CALHOUN, A.J.K., FELIPELUCIA, M.R., FITZSIMONS, J.A., GONZÁLEZ, E., KINNISON, M., LINDENMAYER, D., LUNDQUIST, C.J., MEDELLIN, R.A., NELSON, E.J. and POSCHLOD, P. Conserving small natural features with large ecological roles: a synthetic overview. Biological Conservation, 2017, 211, 88-95. http://dx.doi.org/10.1016/j.biocon.2016.12.020.

JENKINS, D.G. and BUIKEMA JUNIOR, A.L. Do similar communities develop in similar sites? A test with zooplankton structure and function. Ecological Monographs, 1998, 68(3), 421-443. http://dx.doi. org/10.1890/0012-9615(1998)068[0421:DSCDI S]2.0.CO;2.

JOCQUE, M., FIELD, R., BRENDONCK, L. and MEESTER, L. Climatic control of dispersalecological specialization trade-offs: a metacommunity process at the heart of the latitudinal diversity gradient? Global Ecology and Biogeography, 2010, 19(2), 244-252. http://dx.doi.org/10.1111/j.14668238.2009.00510.x.

JUNK, W.J., AN, S., FINLAYSON, C.M., GOPAL, B., KVĚT, J., MITCHELL, S.A., MITSCH, W.J. and ROBARTS, R.D. Current state of knowledge regarding the world's wetlands and their future under global climate change: a synthesis. Aquatic Sciences, 2013, 75(1), 151-167. http://dx.doi.org/10.1007/ s00027-012-0278-z.

KAHMEN, A., RENKER, C., UNSICKER, S.B. and BUCHMANN, N. Niche complementarity for nitrogen: an explanation for the biodiversity and ecosystem functioning relationship? Ecology, 2006, 87(5), 1244-1255. http://dx.doi.org/10.1890/00129658(2006)87[1244:NCFNAE]2.0.CO;2. PMid:16761603.

KOSTE, W. Rotatoria: Die Rädertiere Mitteleuropas. Berlin: Gebrüder Borntraeger, 1978.

LALIBERTÉ, E. and LEGENDRE, P. A distance-based framework for measuring functional diversity from 
multiple traits. Ecology, 2010, 91(1), 299-305. http:// dx.doi.org/10.1890/08-2244.1. PMid:20380219.

LITCHMAN, E., OHMAN, M.D. and KIORBOE, T. Trait-based approaches to zooplankton communities. Journal of Plankton Research, 2013, 35(3), 473-484. http://dx.doi.org/10.1093/plankt/fbt019.

LOPES, P.M., BOZELLI, R.L., BINI, L.M., SANTANGELO, J.M. and DECLERCK, S.A.J. Contributions of airborne dispersal and dormant propagule recruitment to the assembly of rotifer and crustacean zooplankton communities in temporary ponds. Freshwater Biology, 2016, 61(5), 658-669. http://dx.doi.org/10.1111/fwb.12735.

LOREAU, M., NAEEM, S., INCHAUsti, P., BENGTSSON, J., GRIME, J.P., HECTOR, A., HOOPER, D.U., HUSTON, M.A., RAFFAELLI, D., SCHMID, B., TILMAN, D. and WARDLE, D.A. Biodiversity and ecosystem functioning: current knowledge and future challenges. Science, 2001, 294(5543), 804-808. http://dx.doi.org/10.1126/ science.1064088. PMid:11679658.

MACEDO-SOARES, P.H.M., PETRY, A.C., FARJALLA, V.F. and CARAMASCHI, E.P. Hydrological connectivity in coastal inland systems: Lessons from a Neotropical fish metacommunity. Ecology Freshwater Fish, 2010, 19(1), 7-18. http:// dx.doi.org/10.1111/j.1600-0633.2009.00384.x.

MACKERETH, F.J.H., HERON, J. and TALLING, J.F. Water analyses: some revised methods for Limnologists. Michigan: Freswater Ecological Association, 1978.

MARGULES, C.R. and PRESSEY, R.L. Systematic conservation planning. Nature, 2000, 405(6783), 243-253. http://dx.doi.org/10.1038/35012251. PMid:10821285.

MASSiCOTTE, P., FRENETTE, J.J., PROUlX, R., PINEL-ALLOUL, B. and BERTOLO, A. Riverscape heterogeneity explains spatial variation in zooplankton functional evenness and biomass in a large river ecosystem. Landscape Ecology, 2014, 29(1), 67-79. http://dx.doi.org/10.1007/s10980013-9946-1.

MEESTER, L., DECLERCK, S., STOKS, R., LOUETTE, G., VAN DE MEUTTER, F., DE BIE, T., MICHELS, E. and BRENDONCK, L. Ponds and Ponds as model systems in conservation biology, ecology and evolutionary biology. Aquatic Conservation, 2005, 15(6), 715-725. http://dx.doi. org/10.1002/aqc.748.

MORI, A.S., FURUKAWA, T. and SASAKI, T. Response diversity determines the resilience of ecosystems to environmental change. Biological Reviews of the Cambridge Philosophical Society, 2013, 88(2), 349-364. http://dx.doi.org/10.1111/brv. 12004. PMid:23217173.

MULLINS, M.L. and DOYLE, R.D. Big things come in small packages: why limnologists should care about small ponds. Acta Limnologica Brasiliensia, 2019, 31(105), e105. http://dx.doi.org/10.1590/ s2179-975x4119.

NORBERG, J. Resource-niche complementarity and autotrophic compensation determines ecosystemlevel responses to increased cladoceran species richness. Oecologia, 2000, 122(2), 264-272. http:// dx.doi.org/10.1007/PL00008855. PMid:28308381.

NUSCH, E.A. and PALMER, G. Biologische methoden fur die praxis der gewasseruntersushung. GWF Wasser/Abwasser, 1975, 116, 562-565. http://dx.doi. org/10.1007/PL00008855. PMid:28308381.

OKSANEN, J., BLANCHET, F.G., FRIENDLY, M., KINDT, R., LEGENDRE, P., MCGLINN, D., MINCHIN, P.R., O'HARA, R.B., SIMPSON, G.L., SOLYMOS, P., STEVENS, M.H.H., SZOECS, E. and WAGNER, H. vegan: Community Ecology Package. R package version 2.5-2. Vienna: R Foundation for Statistical Computing, 2018.

OSKARSSON, A. and WRIGHT, M.C. Ionic liquids: new emerging pollutants, similarities with Perfluorinated Alkyl Substances (PFASs). Environmental Science \& Technology, 2019, 53(18), 10539-10541. http://dx.doi.org/10.1021/acs. est.9b04778. PMid:31442027.

PAVOINE, S., VALLET, J., DUFOUR, A.-B., GACHET, S. and DANIEL, H. On the challenge of treating various types of variables: application for improving the measurement of functional diversity. Oikos, 2009, 118(3), 391-402. http://dx.doi. org/10.1111/j.1600-0706.2008.16668.x.

PETCHEY, O.L. and GASTON, K.J. Functional diversity (FD), species richness and community composition. Ecology Letters, 2002, 5(3), 402-411. http://dx.doi. org/10.1046/j.1461-0248.2002.00339.x.

PETCHEY, O.L. Integrating methods that investigate how complementarity influences ecosystem functioning. Oikos, 2003, 101(2), 323-330. http:// dx.doi.org/10.1034/j.1600-0706.2003.11828.x.

PINCEEL, T., BUSCHKE, F., WECKX, M., BRENDONCK, L. and VANSCHOENWINKEL, B. Climate change jeopardizes the persistence of freshwater zooplankton by reducing both habitat suitability and demographic resilience. BMCEcology, 2018, 18(1), 2. http://dx.doi.org/10.1186/s12898018-0158-z. PMid:29361977.

PINCEEL, T., HAWINKEL, W., WYNANTS, E., BRENDONCK, L. and VANSCHOENWINKEL, B. Habitat uncertainty explains variation in offspring provisioning strategies in a temporary pond crustacean. Hydrobiologia, 2017, 801(1), 141-151. http://dx.doi.org/10.1007/s10750-017-3121-7.

POWELL, J.S.V. and BABBITT, K.J. Buffer-mediated effects of clearcutting on in-Pond amphibian productivity: Can aquatic processes compensate for terrestrial habitat disturbance? Forests, 2016, 8(1), 10. http://dx.doi.org/10.3390/f8010010. 
PRESSEY, R.L., HUMPHRIES, C.J., MARGULES, C.R., VANE-WRIGHT, R.I. and WILLIAMS, P.H. Beyond opportunism: Key principles for systematic reserve selection. Trends in Ecology \& Evolution, 1993, 8(4), 124-128. http://dx.doi.org/10.1016/01695347(93)90023-I. PMid:21236127.

R CORE TEAM. $R$ : a language and environment for statistical computing [online]. Vienna: R Foundation for Statistical Computing, 2018 [viewed 27 May 2020]. Available from: https://www.R-project.org/

RUBBO, M.J., COLE, J.J. and KIESECKER, J.M. Terrestrial subsidies of organic carbon support net ecosystem production in temporary forest ponds: evidence from an ecosystem experiment. Ecosystems, 2006, 9(7), 1170-1176. http://dx.doi.org/10.1007/ s10021-005-0009-6.

RUSSI, D., TEN BRINK, P., FARMER, A., BADURA, T., COATES, D., FORSTER, J., KUMAR, R. and DAVIDSON, N. The economics of ecosystems and biodiversity for water and wetlands. London: Ramsar Secretariat, 2013.

SANTANGELO, J.M., BOZELLI, R.L., ROCHA, A.M. and ESTEVES, F.A. Effects of slight salinity increases on Moina micrura (Cladocera) populations: field and laboratory observations. Marine and Freshwater Research, 2008, 59(9), 808-816. http:// dx.doi.org/10.1071/MF08026.

SANTANGELO, J.M., ESTEVES, F.A., MANCA, M. and BOZELLI, R.L. Disturbances due to increased salinity and the resilience of zooplankton communities: the potential role of the resting egg bank. Hydrobiologia, 2013, 722(1), 103-113. http:// dx.doi.org/10.1007/s10750-013-1683-6.

SANTANGELO, J.M., ROCHA, A.M., BOZELLI, R.L., CARNEIRO, L.S. and ESTEVES, F.A. Zooplankton responses to sandbar opening in a tropical eutrophic coastal lagoon. Estuarine, Coastal and Shelf Science, 2007, 71(3-4), 657-668. http:// dx.doi.org/10.1016/j.ecss.2006.09.021.

SCARANO, F.R. Biodiversity sector: risks of temperature increase to biodiversity and ecosystems. In: C. NOBRE, J. MARENGO and W. SOARES, eds. Climate change risks in Brazil. Cham: Springer, 2019. p. 131-141.

SCHEFFER, M., VAN GEEST, G.J., ZIMMER, K., JEPPESEN, E., SØNDERGAARD, M., BUTLER, M.G., HANSON, M.A., DECLERCK, S. and DE MEESTER, L. Small habitat size and isolation can promote species richness: Second-order effects on biodiversity in shallow lakes and ponds. Oikos, 2006, 112(1), 227-231. http://dx.doi.org/10.1111/j.00301299.2006.14145.x.

SCHRIEVER, T.A., CADOTTE, M.W. and WILLIAMS, D.D. How hydroperiod and species richness affect the balance of resource flows across aquatic-terrestrial habitats. Aquatic Sciences, 2014,
76(1), 131-143. http://dx.doi.org/10.1007/s00027013-0320-9.

SEMINARA, M., VAGAGGINI, D. and MARGARITORA, F.G. Differential responses of zooplankton assemblages to environmental variation in temporary and permanent ponds. Aquatic Ecology, 2008, 42(1), 129-140. http://dx.doi.org/10.1007/ s10452-007-9088-0.

SERRANO, L. and FAHD, K. Zooplankton communities across a hydroperiod gradient of temporary ponds in the Doñana National Park (SW SPAIN). Wetlands, 2005, 25(1), 101-111. http:// dx.doi.org/10.1672/0277-5212(2005)025[0101:ZC AAHG]2.0.CO;2.

SETUBAL, R.B., PETRY, A.C., BONECKER, C.C., MARTINS, T., NOVA, C.C., FIGUEIREDOBARROS, M.P. and BOZELLI, R.L. Biotic factors determine ecosystem processes in environments with different hydrological regimes. Freshwater Biology, 2020, 65(8), 1376. http://dx.doi.org/10.1111/ fwb. 13506 .

SETUBAL, R.B., SANTANGELO, J.M., ROCHA, A.M. and BOZELLI, R.L. Effects of sandbar openings on the zooplankton community of coastal lagoons with different conservation status. Acta Limnologica Brasiliensia, 2013, 25(3), 246-256. http://dx.doi. org/10.1590/S2179-975X2013000300005.

SHURIN, J.B. Dispersal limitation, invasion resitance, and the structure of pond zooplankton commnities. Ecology, 2000, 81(11), 3074-3086. http://dx.doi. org/10.1890/0012-9658(2000)081[3074:DLIRA T]2.0.CO;2.

SHURIN, J.B., HAVEL, J.E., LEIBOLD, M.A. and PINEL-ALLOUL, B. Local and regional zooplankton species richness: a scale-independent test for saturation. Ecology, 2000, 81(11), 3062-3073. http:// dx.doi.org/10.1890/0012-9658(2000)081[3062:LA RZSR]2.0.CO;2.

TILMAN, D., KNOPS, J., WEDIN, D., REICH, P., RITCHIE, M. and SIEMANN, E. The influence of functional diversity and composition on ecosystem processes. Science, 1997, 277(5330), 1300-1302. http://dx.doi.org/10.1126/science.277.5330.1300.

VANE-WRIGHT, R.I., HUMPHRIES, C.J. and WILLIAMS, P.H. What to protect? The agony of choice. Biological Conservation, 1991, 55(3), 235-254. http://dx.doi.org/10.1016/0006-3207(91)90030-D.

VANSCHOENWINKEL, B., HULSMANS, A., DE ROECK, E., DE VRIES, C., SEAMAN, M. and BRENDONCK, L. Community structure in temporary freshwater Ponds: disentangling the effects of habitat size and hydroregime. Freshwater Biology, 2009, 54(7), 1487-1500. http://dx.doi. org/10.1111/j.1365-2427.2009.02198.x.

VILLÉGER, S., MASON, N.W.H. and MOUILLOT, D. New multidimensional functional diversity 
indices for a multifaceted framework in functional ecology. Ecology, 2008, 89(8), 2290-2301. http:// dx.doi.org/10.1890/07-1206.1. PMid:18724739.

WALKER, B., KINZIG, A. and LANGRIDGE, J. Plant attribute diversity, resilience, and ecosystem function: the nature and significance of dominant and minor species. Ecosystems, 1999, 2(2), 95-113. http://dx.doi. org/10.1007/s100219900062.
WILLIAMS, P.H. Complementarity. In: S. A. LEVIN, ed. Encyclopedia of biodiversity. San Diego: Academic Press, 2011, pp. 813-829.

Received: 27 May 2020

Accepted: 10 July 2020

Associate Editor: André Andrian Padial. 